Bangladesh J. Bot. 49(2): 335-341, 2020 (June)

\title{
RESPONSES OF NAPHTHALENE ACETIC ACID AND PSEUDOMONAS INOCULUM ON GROWTH, YIELD AND SOME BIOCHEMICAL PARAMETERS OF SESAME (SESAMUM INDICUM L. VAR. BARI TIL-4)
}

\author{
Shawline Ema, AMM Golam Adam*, Farhana Islam Khan \\ and Hasna Hena Begum
}

Department of Botany, Jagannath University, Dhaka-1100, Bangladesh

Keywords: Sesame, NAA, Pseudomonas, Growth, Yield, Biochemical response

\begin{abstract}
An experiment was conducted to evaluate the responses of various concentrations of NAA $(25,50,75$ ppm) and Pseudomonas inoculum on growth, yield and some biochemical parameters of sesame (Sesamum indicum L. var. BARI Til-4). Results revealed that application of NAA treatments and Pseudomonas inoculum reduced plant height non-significantly. Significant result was recorded on number of branches per plants from $50 \mathrm{ppm}$ NAA treated plants. Plants treated with $75 \mathrm{ppm}$ NAA produced maximum number of leaves, fresh and dry weight of leaves and roots, leaf area per plant and specific leaf weight whereas significant variation was found on leaf area. Seeds treated with Pseudomonas inoculum exhibited maximum shoot and root ratio which showed non-significant variation with the results of NAA treated plants. Yield contributing parameters viz., number of pods per plant, fresh and dry weight of pods per plant, 1000-seed weight were recorded maximum from 75 ppm NAA which were statistically similar to control. Maximum length of pod and number of seeds per pod were also recorded from 75 ppm NAA treated plants which eventually produced $32.54 \%$ higher yield than control. Harvest index was significantly influenced by all the treatments. Foliar NAA treatments and Pseudomonas inoculum had stimulatory effects on pigment contents of fresh leaves at vegetative stage where, Pseudomonas inoculum treated plants produced significantly higher chlorophyll a and carotenoids content than control. Significantly higher protein content of fresh leaves and seeds were also recorded from 75 ppm NAA treated plants. Out of four treatments, 75 ppm NAA produced better responses in most of the parameters.
\end{abstract}

\section{Introduction}

Sesame (Sesamum indicum L.) is one of the ancient oilseed crops cultivated from tropical to temperate regions of the world under the family Pedaliaceae. It occupies fifth position as an oil crop in Bangladesh and plays vital role in human diet having high per cent of oil (42 - 45), protein (20) and carbohydrate (14.20). Seed contains 47\% oleic, 39\% linoleic acid and rich in omega 6 fatty acid (BARI 1998). Currently the annual demand of oil seeds is approximately 1.4 million metric ton whereas the production at national level is only 0.4 million metric ton (Azad et al. 2017). Acute shortage of this edible oil has been prevailing in Bangladesh during the last several decades and about $70 \%$ of this shortage has been met through imports, using a huge amount of foreign exchange every year. To meet the demand of oilseeds, Bangladesh needs to improve cultivation of oilseed crops for attaining self-sufficiency in the country. In addition, the yield of sesame is very low in the country due to lack of proper management practices (Rahman et al. 1994). The yield of sesame could be increased by using numerous improved technologies and practices where, application of growth regulators and plant growth promoting bacteria is considered as the easiest ways for such an attempt.

Some investigations have showed that naphthalene acetic acid (NAA) had stimulatory effect on different oil seeds crops including sesame (Govindan et al. 2000, Haque 2005, Behera 2015,

*Author for correspondence: <adam_du04@yahoo.com>. 
Siddik et al. 2016). On the other hand, Pseudomonas, a plant growth promoting bacterum, stimulates plant growth through different mechanisms and can also reduce the demand of chemical fertilizers (Glick 2004). Findings of Hasanpour et al. (2012) revealed that plant growth promoting rhizobacteria had advantageous effect on qualitative characters of sesame. The role of Pseudomonas flurescens on the growth of rapeseed has also been evaluated by Yousefi and Heshmatpour (2013). But research work using Pseudomonas sp. on any variety of sesame is not reported from elsewhere of the world. Thus, an attempt was made to investigate the effect of foliar application of NAA and Pseudomonas inoculum on growth, yield and biochemical parameters of sesame.

\section{Materials and Methods}

A field experiment was carried out at the Botanical garden of the Department of Botany, Jagannath University, Dhaka during the period of 2015 - 2016. Experimental soil was sandy loam and according to Fertilizer Recommendation Guide (2012) soil contains very low amount of nitrogen $(0.069 \%)$, very high amount of phosphorus $(80.17 \mu \mathrm{g} / \mathrm{g})$ and very low amount of potassium $(0.065 \mathrm{meq} / 100 \mathrm{~g})$. A modern variety of sesame, BARI Til-4 was used as an experimental material. The experiment was laid out in RBD with three replications. Seeds of BARI Til-4 and the strain of Pseudomonas sp. were collected from Bangladesh Agricultural Research Institute (BARI). The total area of the experimental field was $36 \mathrm{~m}^{2}(6 \mathrm{~m} \times 6 \mathrm{~m})$. The experiment consisted of five treatments viz., $\mathrm{T}_{0}=$ Control (distilled water), $\mathrm{T}_{1}=$ Seed inoculated with Pseudomonas sp. $\mathrm{T}_{2}=25 \mathrm{ppm} \mathrm{NAA}, \mathrm{T}_{3}=50 \mathrm{ppm}$ NAA and $\mathrm{T}_{4}=75 \mathrm{ppm}$ NAA. Seeds were surface-sterilized with $95 \%$ ethanol for 5 min and rinsed 6 times with sterile water, then dried overnight in a sterile blotting paper (Atici et al. 2005). Surface sterilized seeds were treated with 1 $\mathrm{ml}$ Pseudomonas sp. cell suspension $(108 \mathrm{cfu} / \mathrm{ml})$. The seeds of sesame were sown on May 2, 2016 maintaining row to row distance of $30 \mathrm{~cm}$ and seed to seed distance of $5 \mathrm{~cm}$. Cultural practices and fertilizer application were done following the Hand Book of Agricultural Technology (Chowdhury and Hassan 2013). Urea as a source of nitrogen was not used in case of bacterial treatment. Foliar application of NAA was done in sunny early morning at the age of 25 days.

Growth parameters viz., plant height, number of branches and leaves per plant, fresh and dry weight of leaves and root per plant, shoot-root ratio, leaf area, specific leaf weight and net assimilation rate were recorded at harvest. Pigment and protein contents of fresh leaves were determined at vegetative and flowering stages. Protein contents of fresh seeds was also determined after harvest. The amount of chlorophyll $\mathrm{a}$ and $\mathrm{b}$ were estimated by using specific absorption coefficient of Mckinney (1940) and the formulae of Maclachalan and Zalik (1963). The amount of carotenoid was calculated using the equation of von Wettstein (1957). The method of Lowry et al. (1951) was employed for the determination of protein content of leaves. Plants were harvested at the age of 90 days. Nine plants from each treatment were harvested separately to record data on different growth and yield parameters. Data were analysed statistically, and treatment means were compared by LSD test at 5\% level of significance (Steel et al. 1997).

\section{Results and Discussion}

Results presented in Table 1 showed that height of BARI Til-4 decreased following all treatments but with non-significant variations. This result is in agreement with the findings of Behera (2005) where height of sesame plant decreased following 10 ppm NAA treatment. However, Haque (2005) and Siddik (2014) reported that height of sesame increased due to NAA application. 
Significantly maximum number of primary branches per plant (9.22) was recorded from the plants treated with $50 \mathrm{ppm}$ NAA. Similar results of increase in number of primary branches per plant following 50 ppm NAA treatment was also reported by Siddik (2014) in sesame. Results revealed that number of leaves per plant, fresh and dry weight of leaves and root per plant, leaf area per plant and specific leaf weight (SLW) were maximum from 75 ppm NAA treatment where it was significantly higher in case of leaf area per plant. Siddik (2014) also obtained higher number of leaves in sesame plant due to NAA treatments which conforms to the findings of present investigation. Verma and Sen (2008) recorded maximum fresh and dry weight of leaves with $20 \mathrm{ppm}$ NAA in coriander plant. Siddik et al. (2014) obtained increased amount of fresh and dry weight of root following NAA treatment in sesame. Behera (2015) reported that application of NAA had stimulatory effect on SLW of sesame. Haque (2005) recorded significant increases in leaf area of sesame with different NAA treatments. Shoot-root ratio also showed positive response to $75 \mathrm{ppm}$ NAA although the maximum was obtained from Pseudomonas treated plants. By applying NAA on soybean, Govindan et al. (2000) found $12.48 \%$ higher shoot-root ratio over the control whereas, Woyessa and Assefa (2011) found 42\% higher shoot-root ratio in Eragrostis tef due to inoculation of Pseudomonas. The maximum net assimilation rate (NAR) was recorded from both control and 75 ppm NAA treatment but statistically identical to rest of the treatments. Results of Behera (2015) revealed that application of 10 and 20 ppm NAA had higher NAR in sesame.

Results on yield attributes and yield of sesame has been presented in Table 2. Number of pods per plant was found to increase following $75 \mathrm{ppm}$ NAA although statistically not different to control. Increased number of pods per plant following NAA treatments has also been previously reported in sesame (Behera 2015, Siddik et al. 2016).

Application of $75 \mathrm{ppm}$ NAA produced significantly longer length of pods than control followed by $50 \mathrm{ppm}$ and Pseudomonas inoculum, respectively. Application of NAA treatments significantly increased the pod length in sesame plant (Siddik et al. 2016). Abdel-Aziz and Salem (2013) recorded affirmative effect of Pseudomonas fluorescens on the pod length of cowpea. Fresh and dry weight of pods per plant and 1000-seed weight were also recorded maximum from 75 ppm NAA although statistically at par with control. Similar results of increase in fresh and dry weight of pods following NAA treatments has also been reported in sesame by other investigators (Haque 2005, Siddik et al. 2016). Results revealed that 75 ppm NAA resulted significantly maximum number of seeds per pod followed by $50 \mathrm{ppm}$ NAA and Pseudomonas inoculum, respectively. Maqsood et al. (1994) found increased number of seeds per pod due to the application of growth promoting Rhizobium bacteria. The maximum 1000-seed weight was also found from $75 \mathrm{ppm}$ NAA treatment but statistically identical to the rest of the treatments. Siddik et al. (2016) reported that application of NAA treatments had higher 1000-seed weight in sesame plant. The positive influence on yield per plant was observed from the plants treated with $75 \mathrm{ppm}$ NAA which was significantly higher than all the treatments. Yield per plant obtained from $75 \mathrm{ppm}$ NAA was $32.54 \%$ higher over control. Increase in yield of sesame due to NAA application has been reported by several other workers (Haque 2005, Behera 2015, Siddik et al. 2016). Harvest index (HI) was significantly influenced by different NAA treatments and Pseudomonas sp. where, the maximum HI was found in $50 \mathrm{ppm}$ NAA application. By applying $50 \mathrm{ppm}$ NAA, Ullah et al. (2007) obtained significantly higher $\mathrm{HI}$ in cowpea. Hasanpour et al. (2012) recorded $18.10 \%$ higher $\mathrm{HI}$ when Pseudomonas fluorescens was used with Azospirillum spp. and Bacillus subtilis as mixed treatment.

Results presented in Table 3 showed that NAA and Pseudomonas application had both significant and non-significant response on pigment content of leaves at vegetative and flowering stages. Pigment content of leaves was positively influenced by most of the treatments at vegetative 

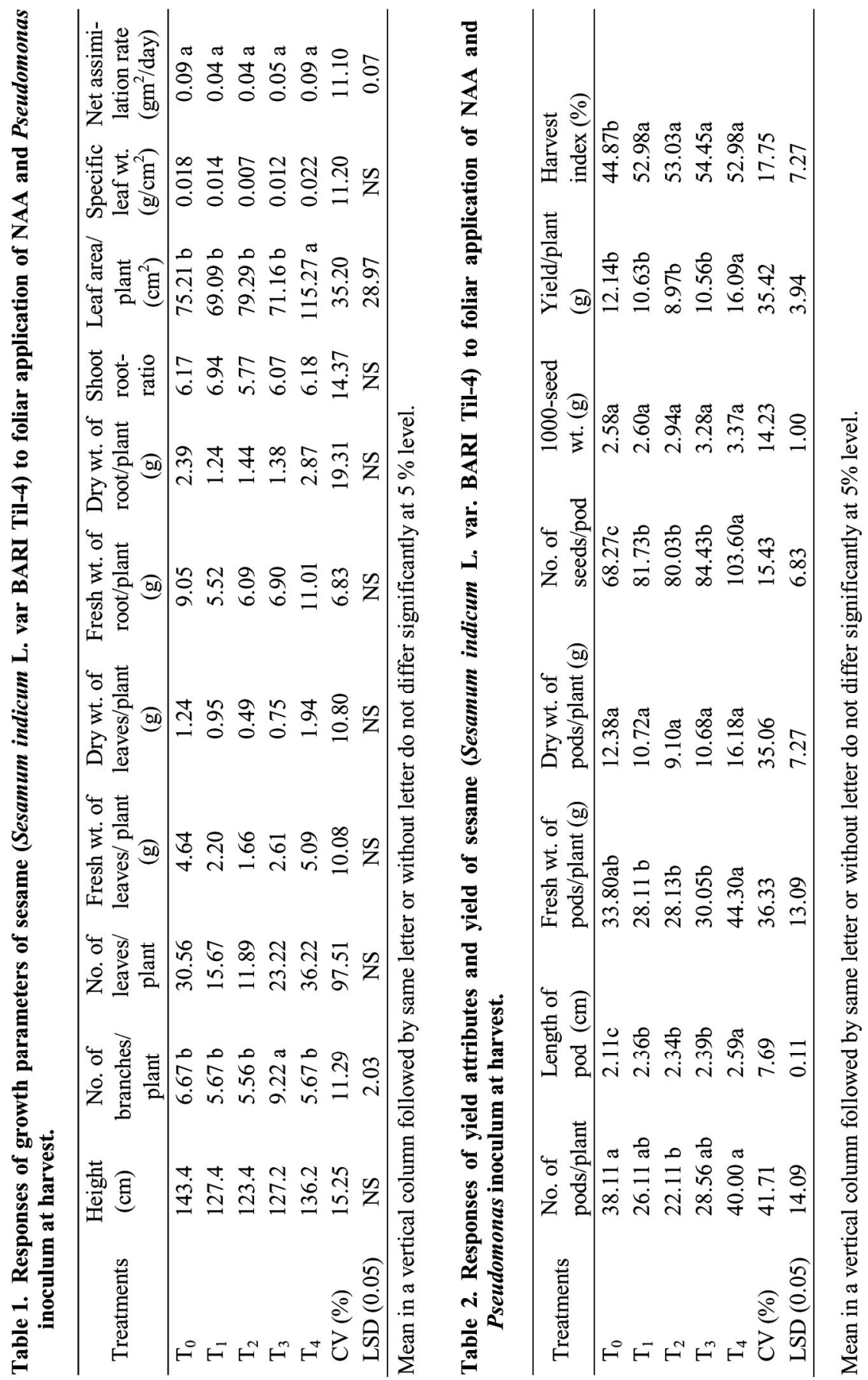
stage whereas, the response was rather negative at flowering stage. Significantly higher chlorophyll a and carotenoids content of leaves were recorded from the inoculation of Pseudomonas treatment at vegetative stage. Prakas (1998) reported that application of NAA treatments had both positive and negative response on the photosynthetic pigments of sesame. Mathivanan et al. (2017) obtained enhanced pigment content in groundnut leaf due to Pseudomonas treatment.

Results presented in Table 4 show that protein content of fresh leaves of BARI Til-4 significantly responded by 50 and $75 \mathrm{ppm}$ NAA treatments at vegetative stage where the maximum amount was noted from $75 \mathrm{ppm}$. Protein content of leaves was significantly influenced following all treatments at flowering stage where, $75 \mathrm{ppm}$ NAA produced significantly maximum value.

Table 3. Responses of pigment content $(\mathrm{mg} / \mathrm{g})$ of fresh leaves of sesame (Sesamum indicum $\mathrm{L}$. var. BARI Til-4) to foliar application of NAA and Pseudomonas inoculum at two different stages.

\begin{tabular}{|c|c|c|c|c|c|c|}
\hline \multirow{2}{*}{ Treatments } & \multicolumn{3}{|c|}{ Vegetative stage } & \multicolumn{3}{|c|}{ Flowering stage } \\
\hline & Chl. a & Chl. b & Carotenoids & Chl. a & Chl. b & Carotenoids \\
\hline $\mathrm{T}_{0}$ & $0.42 \mathrm{~b}$ & 0.29 & $4.15 b$ & 0.86 & $0.86 \mathrm{a}$ & $6.87 \mathrm{a}$ \\
\hline $\mathrm{T}_{1}$ & $0.73 \mathrm{a}$ & 0.40 & $7.12 \mathrm{a}$ & 0.72 & $0.46 \mathrm{ab}$ & $6.79 \mathrm{a}$ \\
\hline $\mathrm{T}_{2}$ & $0.47 \mathrm{~b}$ & 0.37 & $5.27 \mathrm{ab}$ & 0.43 & $0.22 \mathrm{~b}$ & $3.21 \mathrm{~b}$ \\
\hline $\mathrm{T}_{3}$ & $0.42 \mathrm{~b}$ & 0.43 & $5.84 a b$ & 0.43 & $0.22 \mathrm{~b}$ & $4.58 \mathrm{ab}$ \\
\hline $\mathrm{T}_{4}$ & $0.36 \mathrm{~b}$ & 0.36 & $5.52 \mathrm{ab}$ & 0.62 & $0.32 \mathrm{~b}$ & $6.56 \mathrm{ab}$ \\
\hline $\mathrm{CV}(\%)$ & 13.62 & 28.35 & 22.13 & 17.65 & 14.93 & 16.19 \\
\hline $\operatorname{LSD}(0.05)$ & 0.20 & NS & 2.10 & NS & 0.51 & 3.38 \\
\hline
\end{tabular}

Mean in a vertical column followed by same letter or without letter do not differ significantly at $5 \%$ level.

Table 4. Responses of protein content ( $\mathrm{mg} / \mathrm{g}$ ) of fresh leaves and seeds of sesame (Sesamum indicum $\mathrm{L}$. var. BARI Til-4) to foliar application of NAA and Pseudomonas inoculum.

\begin{tabular}{lccc}
\hline \multirow{2}{*}{ Treatments } & \multicolumn{2}{c}{ Protein content of fresh leaves $(\mathrm{mg} / \mathrm{g})$} & Protein content of seeds $(\mathrm{mg} / \mathrm{g})$ \\
\cline { 2 - 4 } & Vegetative stage & Flowering stage & At harvest \\
\hline $\mathrm{T}_{0}$ & $47.01 \mathrm{~b}$ & $11.19 \mathrm{c}$ & $187.63 \mathrm{~b}$ \\
$\mathrm{~T}_{1}$ & $45.50 \mathrm{~b}$ & $17.75 \mathrm{~b}$ & $204.75 \mathrm{~b}$ \\
$\mathrm{~T}_{2}$ & $51.75 \mathrm{~b}$ & $16.75 \mathrm{~b}$ & $223.75 \mathrm{~b}$ \\
$\mathrm{~T}_{3}$ & $90.63 \mathrm{a}$ & $18.00 \mathrm{~b}$ & $300.13 \mathrm{a}$ \\
$\mathrm{T}_{4}$ & $100.88 \mathrm{a}$ & $23.88 \mathrm{a}$ & $294.00 \mathrm{a}$ \\
$\mathrm{CV}(\%)$ & 37.81 & 25.55 & 21.48 \\
$\mathrm{LSD}(0.05)$ & 19.69 & 4.47 & 50.93 \\
\hline
\end{tabular}

Mean in a vertical column followed by same letter or without letter do not differ significantly at $5 \%$ level.

Results also indicated that $50 \mathrm{ppm}$ NAA had resulted significantly higher amount of seed protein than control but statistically similar to 75 ppm NAA treatment. Outcome of Haque (2005) revealed that protein content of sesame leaves progressively increased with the increasing in 
concentration of NAA. By applying Pseudomonas aeruginosa LES4, Kumar et al. (2009) obtained $10.30 \%$ higher seed protein than control. Thus, this result is in accord with the findings of previous workers.

\section{References}

Abdel-Aziz MA and Salem MF 2013. Effect of microbial inoculation on reduction of cowpea (Vigna unguiculata, L. Walp) chemical fertilizers under newly reclaimed soils condition in Egypt. J. Plant Production, Mansoura Univ. 4(5): 745-761.

Atici O, Ogutcu H and Algur OF 2005. Effect of putrescine on inducing symbiosis in chickpea and vetch inoculated with commercial or indigenous strains of Rhizobium. Symbiosis 38: 163-174.

Azad AK, Rahman L, Gosami BK, Malakar PK, Hasan S, Barma NCD, Pal TK, Aziz A, Hossen S, Alam SN, Hasaan K, Rahman B and Rahman HH 20017. Krishi Projukti Manual (Agro-technology Manual). Bangladesh Agricultural Research Institute, Gazipur 1701, Bangladesh. pp. 292.

Bangladesh Agricultural Research Institute (BARI) 1998. Til Fasalar Chass. Bangladesh Agricultural Research Institute, Joydebpur, Gazipur. pp. 30-31.

Behera S 2015. Effect of plant growth regulators on growth and yield characters of Sesamum. M.Sc. Thesis (published). Department of Plant Physiology, Odissa University of Agriculture and Technology, Bhubaneswar.

Chowdhury MAH and Hassan MS (Ed) 2013. Hand Book of Agricultural Technology. Bangladesh Agricultural Technology. Bangladesh Agricultural Research Council, Farmgate, Dhaka. pp. 230.

Fertilizer Recommendation Guide 2012. Bangladesh Agricultural Research Council, Farmgate, Dhaka-1215. pp. 274.

Glick BR 2004. Promotion of plant growth by soil bacteria that regulate plant ethylene levels'. Plant Physiology 251: 1-7.

Govindan K, Thirumurugan V and Arulchelvan S 2000. Response of soybean to growth regulators. Res. Crops India. 1: 323-325.

Hasanpour R, Pirdashti H, Esmaeili MA and Abbasian A 2012. Effect of plant growth promoting rhizobacterial (PGPR) and nitrogen on qualitative characteristics of sesame (Sesamum indicum L.) cultivars. Int. J. Agric. Crop Sci. 4(11): 662-665.

Kumar S, Pandey P and Maheshwari DK 2009. Reduction in dose of chemical fertilizers and growth enhancement of sesame (Sesamum indicum L.) with application of rhizospheric competent Pseudomonas aeruginosa LES4. Eur. J. Soil Biol. 45: 334-340.

Lowry OH, Rosebrough NJ, Farr AL and Randall RJ 1951. Protein measurement with folin phenol reagent. J. Boil. Chem. 193: 265-275.

Maclachalan S and Zalik S 1963. Plastid structure, chlorophyll concentration and free amino acid composition of a chlorophyll mutant of barley. Can. J. Bot. 41: 1053-1062.

Maqsood M, Hussain A, Khaliq A and Nawaz M 1994. Effect of Rhizobium inoculation and phosphorus on nodulation and yield of lentil (Lens culinaris Medic). Pak. J. Agri. Sci. 31: 41-43.

Mathivanan S, Chidambaram ALA, Amalan GR and Kalaikandhan R 2017. Impact of PGPR inoculation on photosynthetic pigment and protein contents in Arachis hypogaea L. J. Sci. Agri. 1: 29-36.

Mckinney G 1940. Criteria for purity of chlorophyll preparations. J. Biol. Chem. 132: 91-107.

Prakash M 1998. Studies on physiological aspects to improve yield in sesame (Sesamum indicum L.). Ph.D. Thesis (Published), Annamalai University, Anamalai Nagar, Tamil Nadu, India.

Rahman MM, Maula MG, Begum S. and Hossain MA 1994. Maximization of yield of sesame through management practices. Central Annual Research BARI, Joydebpur, Gazipur, pp. 36-53.

Siddik A, Shirazy BJ, Islam MM, Haque A and Haque M 2016. Combined effect of nitrogen and NAA on sesame (Sesammum indicum L.). Int. J. Biom. Sci. Engi. 3(1): 7-1. 
Siddik MA 2014. Morphological characters, yield attributes and yield of sesame (sesamum indicum L.) as influenced by nitrogen and NAA. M.Sc. thesis (published), Dept. of Agricultual Botany, Sher-e-Bangla Agricultural University, Dhaka, Bangladesh.

Steel RGD, Torrie JH and Dickey DA 1997. Principles and procedures of statistics. McGraw Hill Book Co. Inc. New York. pp. 666.

Ullah MJ, Fattah QA and Hossain F 2007. Response of growth, yield attributes and yield to the application of KNap and NAA in cowpea (Vigna unguiculata L. WALP). Bangladesh J. Bot. 36(2): 127-132.

Verma P and Sen NL 2008. Growth and biochemical constituents of coriander (Coriandrum sativum L.). J. Herbs Spices Medicinal Plants. 14(3-4): 144-153.

Wettstein DV 1957. Chlorophyll-lethal under sub-mikroskopishe, formweschseder plastiden. Expt. Cell Res. 12: $427-507$.

Woyessa D and Assefa F 2011. Effects of plant growth promoting rhizobaceria on growth and yield of Tef (Eragrostis tef Zucc.Trotter) under greenhouse condition. Res. J. Microbiol. 6: 343-355.

Yousefi M and Heshmatpour N 2013. The role of Pseudomonas flurescens strains in growth and phosphate concentration of rapeseed (Brassica napus L.). Iranian J. Pl. Physiol. 3(4): 829-833.

(Manuscript received on 21 February, 2019; revised on 23 August, 2019) 